\title{
造血幹細胞移植患者におけるシクロスポリンAと アゾール系抗真菌剤との相互作用の評価
}

\author{
黑松 誠 ${ }^{* 1}$, 梶田貴司 ${ }^{1}$, 樽野麻依 ${ }^{1}$, 西川 豊 ${ }^{1}$, 雪矢良輔 ${ }^{1}$, 飯岡 大 $^{2}$ \\ 前迫善智 ${ }^{2}$, 中村文彦 ${ }^{2,3}$, 大野仁嗣 ${ }^{2}$, 上田睦明 ${ }^{1}$, 中塚英太郎 ${ }^{1}$ \\ 公益財団法人天理よろづ相談所病院薬剂部 ${ }^{1}$, 血液内科 ${ }^{2}$, 臨床病理部 $^{3}$

\section{Evaluation of the Drug Interactions between Cyclosporin A and Azole Antifungals in Hematopoietic Stem Cell Transplant Recipients}

\begin{abstract}
Makoto Kuromatsu ${ }^{* 1}$, Takashi Kajita', Mai Taruno ${ }^{1}$, Yutaka Nishikawa ${ }^{1}$, Ryousuke Yukiya ${ }^{1}$, Futoshi Iioka ${ }^{2}$, Yoshitomo Maesako, Fumihiko Nakamura ${ }^{2,3}$, Hitoshi Ohno ${ }^{2}$, Mutsuaki Ueda ${ }^{1}$ and Eitarou Nakatsuka ${ }^{1}$ Department of Pharmacy ${ }^{1}$, Department of Hematology ${ }^{2}$, Department of Clinical Pathology ${ }^{3}$, Tenri Hospital
\end{abstract}

\author{
$\left[\begin{array}{l}\text { Received April 24, 2012 } \\ \text { Accepted August 24, 2012 }\end{array}\right]$
}

Cyclosporin A (CyA) and azole antifungals are clinically co-administered to patients after allogeneic hematopoietic stem cell transplantation (HSCT). Since CyA is a substrate of P450 (CYP3A4) and/or P-glycoprotein in the liver and the intestine, concomitant use of CyA and azole antifungals might increase the concentration of CyA in the blood. The purpose of this study was to evaluate the effects of antifungals on the blood concentration of CyA in allogeneic HSCT recipients. When CyA was orally administered, the magnitude of drug interactions between CyA and the antifungals on CyA concentration were: oral itraconazole (ITZ) solution $>$ voriconazole (VCZ) tablet $>$ ITZ capsule $>$ fluconazole (FCZ) capsule. The concentration/dose ratio of CyA increased with each antifungal but the difference from control was only significant with oral ITZ solution $(P<0.001)$. When CyA was intravenously (iv.) administered, the magnitude of drug interactions on CyA clearance was: iv. ITZ injection and VCZ tablet $>$ oral ITZ solution $>$ FCZ capsule $>$ iv. fosfluconazole injection and ITZ capsule. Significant decreases in CyA clearance versus control were seen with iv. ITZ injection $(P<0.001)$, VCZ tablet and oral ITZ solution $(P<0.05)$. The present study confirmed that the magnitude of the drug interactions between CyA and azole antifungals varies by dosage form as well as by the potency of the azole inhibitor. These results provide a better understanding of the drug interactions between immunosuppressants and azole antifungals. In addition, this information may contribute to the effectiveness and safety of immunosuppressant therapy.

Key words — cyclosporin A, azole antifungals, drug interaction, hematopoietic stem cell transplant recipients, therapeutic drug monitoring

\section{緒 言}

シクロスポリン A（CyA）は，各種臟器移植 時の拒絶反応の防止に用いられるが，造血幹細胞 移植時においては移植片対宿主病 (Graft versus host disease: GVHD）を防止する目的で用いられ る. GVHDは移植されたドナーのリンパ球が患 者の組織を異物とみなし免疫学的に攻撃するもの で, 症状は発熱, 皮膚症状, 肝機能障害, 消化器
症状，眼症状など多岐にわたる。重篤な GVHD は治療を妨げ患者の生命を脅かすためその防止が 必須であり, 特に移植直後に生じる急性 GVHD 防止のため, 移植直前よりCyA が投与される. CyA は強力な免疫抑制作用を示す一方で, その 薬物動態は個体間, 個体内での変動が大きく有効 治療域も狭いため, 安全かつ有効な治療を行うた めには治療薬物濃度モニタリング（TDM）が必 要不可欠である。 また, 肝臟や一部消化管に存在

\footnotetext{
*奈良県天理市三島町200番地
} 
する薬物代謝酵素であるチトクローム $\mathrm{P} 450$ (CYP) 3A4 や P 糖タンパク質の基質であること から，これらを阻害する薬剤との併用により，そ の薬物動態が変動することが知られている. ${ }^{1,2}$

アゾール系抗真菌剤は, 造血幹細胞移植後の免 疫抑制状態で発症する真菌症の治療や予防に沉用 され, 本邦では, イトラコナゾール, ボリコナゾー ル，フルコナゾール等，数種類の薬剤が上市され ている。これらアゾール系の抗真菌剤は, それぞ れが CYP3A4 や P 糖タンパク質の阻害作用を有 することから CyA との併用時, その薬物動態に 影響を及ぼす可能性が高く, ${ }^{3-6)}$ 添付文書上でも併 用注意となっている。しかし，これらの薬剤との 相互作用を考慮した投与量調節の目安については 十分な検討がなされておらず，特に造血幹細胞移 植後は，患者の病状や病態が短期間で変動するた め，アゾール系抗真菌剤の種類や剂型，投与経路 が頻繁に変更され，この薬物間相互作用が CyA
血中濃度を有効域に保つことを困難としている。 そこで我々は, 造血幹細胞移植施行患者を対象 としてアゾール系抗真菌剤の種類や投与経路の違 いによる CyA 薬物動態への影響について調査を 行い, CyAの臨床的投与量調節の必要性につい て検討した。

\section{方法}

\section{1. 対象}

2003 年 1 月〜 2010 年 6 月に天理よろづ相談所 病院において造血幹細胞移植が施行された患者の うち, CyA（ネオーラル カ カプセル（ネオーラル ${ }^{\circledR}$ 内用液 2 例を含む)）が経口投与された 40 例（男 性 25 例, 女性 15 例, 年齢 $50 \pm 13$ (平均 \pm 標 準偏差)）と CyA（サンディミュン注射）を 24 時間持続静脈内投与した 57 例（男性 35 例，女性 22 例，年齢 $50 \pm 13 ）$ を対象とした（表 1).

表 1 患者背景

\begin{tabular}{|c|c|c|}
\hline CyA 投与方法 & 経口投与群 & 静脈内投与群 \\
\hline 症例数 a) & 40 & 57 \\
\hline 性別（男 /女） & $25 / 15$ & $35 / 22$ \\
\hline 年齢（歳） & $50 \pm 13$ & $50 \pm 13$ \\
\hline 体重（kg） & $54 \pm 10$ & $57 \pm 9$ \\
\hline CyA 投与量 (mg/kg/day ) & $3.1 \pm 1.4$ & $2.9 \pm 0.7$ \\
\hline CyA 血中濃度（ng/mL） & $246 \pm 120$ & $405 \pm 106$ \\
\hline \multicolumn{3}{|l|}{ 原疾患 } \\
\hline 急性骨髄性白血病 & 13 & 21 \\
\hline 急性リンパ性白血病 & 4 & 11 \\
\hline 悪性リンパ腫 & 6 & 9 \\
\hline 成人 $T$ 細胞白血病 & 3 & 5 \\
\hline 骨髄異形成症候群 & 3 & 4 \\
\hline 再生不良性貧血 & 3 & 2 \\
\hline 慢性骨髄性白血病 & 1 & 3 \\
\hline その他 & 7 & 2 \\
\hline \multicolumn{3}{|l|}{ アゾール系抗真菌剤 } \\
\hline 対照群（併用なし） & $9^{\text {b) }}$ & $14^{\mathrm{c})}$ \\
\hline FCZ カプセル（200 mg/day） & 9 & $13^{\text {d) }}$ \\
\hline FFCZ 注（200 mg/day） & - & $9^{\text {d) }}$ \\
\hline ITZ カプセル（200mg/day） & 11 & $7^{\text {d) }}$ \\
\hline ITZ 内用液（200 mg/day） & 13 & $11^{d)}$ \\
\hline ITZ 注（200 mg/day） & - & $9^{\text {d) }}$ \\
\hline VCZ 錠 $(300 \mathrm{mg} /$ day $)$ & 4 & $3^{\text {d) }}$ \\
\hline
\end{tabular}

a) 経口および静脈内投与群のいずれにも該当する症例：23例

b) 対照群および併用群いずれにも該当する症例 : 6 例

c) 対照群および併用群いずれにも該当する症例：3例

d) 同一症例内で 2 種以上のアゾール系抗真菌剤が併用されている症例 : 9 例 


\section{CyA 投与および血中濃度測定方法}

CyA 投与法として, 経口投与群では 1 日量を 1 日 2 回に分けて投与し，静脈内投与群では 24 時 間持続投与した。平均投与量は経口投与群で 3.1 $\pm 1.4 \mathrm{mg} / \mathrm{kg} / \mathrm{day}$, 静脈内投与群で $2.9 \pm 0.7 \mathrm{mg} / \mathrm{kg} /$ dayであった。 また，経口投与群の採血は，最低 血中濃度（トラフ值）となるようネオーラル®服 用直前の朝に実施した。なお，CyA 血中濃度測 定には $\operatorname{AxSYM}^{\circledast}$ (アボットジャパン(株)）を用い 蛍光偏光免疫法（FPIA 法）により測定した. ${ }^{7)}$

\section{3. 評価方法}

添付文書記載の CyA 血中濃度に影響を及ぼす薬 剂との併用がない症例を対照群とし，各アゾール 系抗真菌剤を併用した群との間で CyA 血中濃度を 比較した，本検討ではアゾール系抗真菌剤として， フルコナゾールカプセル（ジフルカン®カプセル， FCZ カプセル), ホスフルコナゾール注（プロジフ® 静注液, FFCZ 注), イトラコナゾールカプセル (イ トリゾール®カプセル，ITZ カプセル），イトラコナ ゾール内用液（イトリゾール®内用液, ITZ 内用液), イトラコナゾール注（イトリゾール®注，ITZ 注）， ボリコナゾール錠（ブイフェンド®錠, VCZ 錠）の 3 成分， 6 製剂を用い，経口投与群では 4 製郕，静 脈内投与群では 6 製剤について検討した。 また, 経口投与群の $\mathrm{CyA}$ 血中濃度 / 投与量 (C/D) 比, 静脈内投与群の全身クリアランス（CL）は，定常 状態時の血中濃度を用い以下に示す式で算出した。

$\cdot \mathrm{C} / \mathrm{D}$ 比 ( $\mathrm{CyA}$ 経口投与群)

$\mathrm{C} / \mathrm{D}$ 比 $(\mathrm{kg} / \mathrm{L})=$ 血中濃度 / 体重当りの投与量

- CL ( CyA 静脈内投与群)

$\mathrm{CL}(\mathrm{mL} / \mathrm{min} / \mathrm{kg})=$ 投与速度 $/$ 血中濃度

抗真菌剤の投与量, 種類, 投与経路が変更され た際には，各薬剤の添付文書に記載のある半減期 を 3 倍した期間内に測定した CyA 血中濃度は解 析から除外した。また，アゾール系抗真菌剤以外 で添付文書記載の CyA 血中濃度に影響を及ぼす 可能性のある薬剤が併用されている期間およびア スパラギン酸アミノトランスフェラーゼ（AST） とアラニンアミノトランスフェラーゼ (ALT) が当院の基準值上限（AST: 32, ALT : 30）の 2 倍 を上回る期間についても対象外とした.

\section{4. 統計学的処理}

対照群と各アゾール系抗真菌剤併用群間の比較 には, Kruskal-Wallis test, Dunn's multiple comparison test を用い，P值が 5\%未満を有意差ありとした。 また，統計解析は Mini StatMate を用いて行った.

\section{5. 倫理的配慮について}

本研究の実施にあたっては, 疫学研究に関する倫 理指針(平成 19 年 8 月 16 日全部改正)に従い, 天理 よろづ相談所病院倫理委員会の承認を得て行った.

\section{結果}

\section{CyA 経口投与時におけるアゾール系抗真菌 剤の影響}

経口投与群では,アゾール系抗真菌剂について, CyA が内服可能であるため, 同じ経口製剤であ る FCZ プセル， ITZカプセル， ITZ 内用液, $\mathrm{VCZ}$ 錠の 4 群を対象とし検討した。その結果, 対照群の C/D 比は $0.047 \pm 0.013 \mathrm{~kg} / \mathrm{L}$ であったの に対し, FCZ カプセル, ITZ カプセル, ITZ 内用液, VCZ 錠併用群は，それぞれ $0.070 \pm 0.025 \mathrm{~kg} / \mathrm{L}$, $0.078 \pm 0.016 \mathrm{~kg} / \mathrm{L}, \quad 0.140 \pm 0.072 \mathrm{~kg} / \mathrm{L}, \quad 0.097 \pm$ $0.021 \mathrm{~kg} / \mathrm{L}$ とすべてのアゾール系抗真菌剂との併 用で C/D 比に上昇を示した（図 1)。特に，ITZ 内用液併用群では, 対照群に比較し $\mathrm{C} / \mathrm{D}$ 比は約 3 倍まで増加し，有意差を認めた $(P<0.001)$.

\section{CyA 静脈内投与時におけるアゾール系抗真 菌剤の影響}

CyA 静脈内投与時における対照群と各アゾール系 抗真菌剤併用群の CL を図 2 に示す．対照群の CL が $6.77 \pm 1.32 \mathrm{~mL} / \mathrm{min} / \mathrm{kg}$ に対し，CL が大きく低下 したのは ITZ 注および VCZ 錠併用群で，それぞれ $3.79 \pm 1.40 \mathrm{~mL} / \mathrm{min} / \mathrm{kg}(P<0.001), 3.64 \pm 0.64 \mathrm{~mL} /$ $\mathrm{min} / \mathrm{kg}(P<0.05)$ と対照群に比べ約 50\%低下した. 続いて, ITZ 内用液群で, CL は $35 \%$ 減少し $4.53 \pm$ $1.16 \mathrm{~mL} / \mathrm{min} / \mathrm{kg}(P<0.05)$ となり, これら ITZ 注, VCZ 錠，ITZ 内用液の 3 製剤では，CL に有意な低 下を認めた，一方, FCZ カプセル, ITZ カプセル, FFCZ 注併用群では 15〜20\%程度 CL が減少したも のの，対照群との間に有意差を示さなかった. 


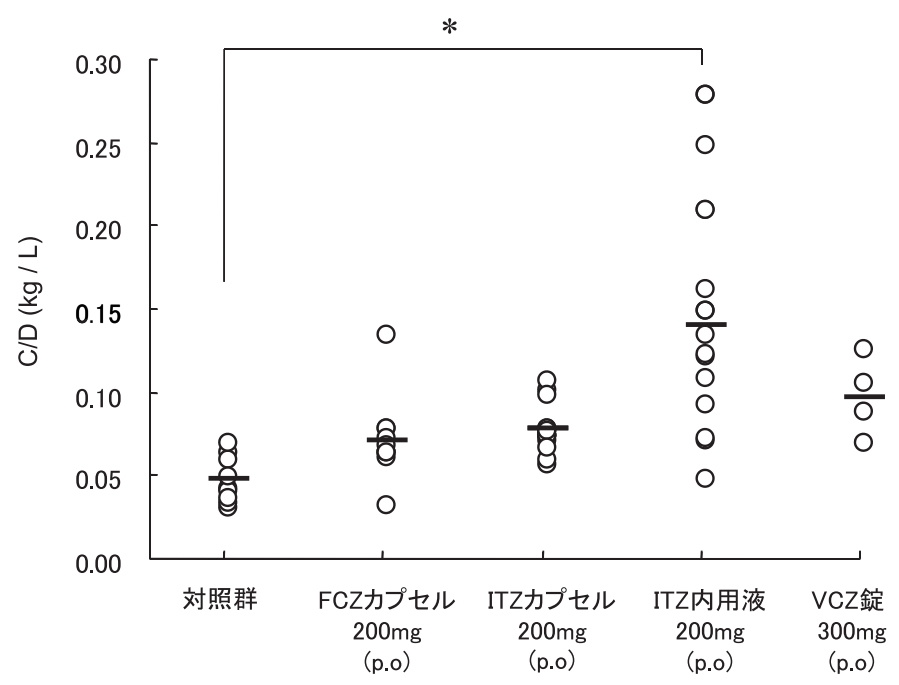

図 1 CyA 経口投与 (p.o) 時の血中濃度/投与量 (C/D) 比に及 ぼすアゾール系抗真菌凨の影響

各ポイント $(\bigcirc)$ は同一患者における同一アゾール系抗真菌片使用下での $\mathrm{C} / \mathrm{D}$ 比の平均值 (測定回数 : $3 \sim 15$ 回), バー (一) は各群の平均值を示す.

${ }^{*} P<0.001$ (Kruskal-Wallis test followed by Dunn's multiple comparison test)

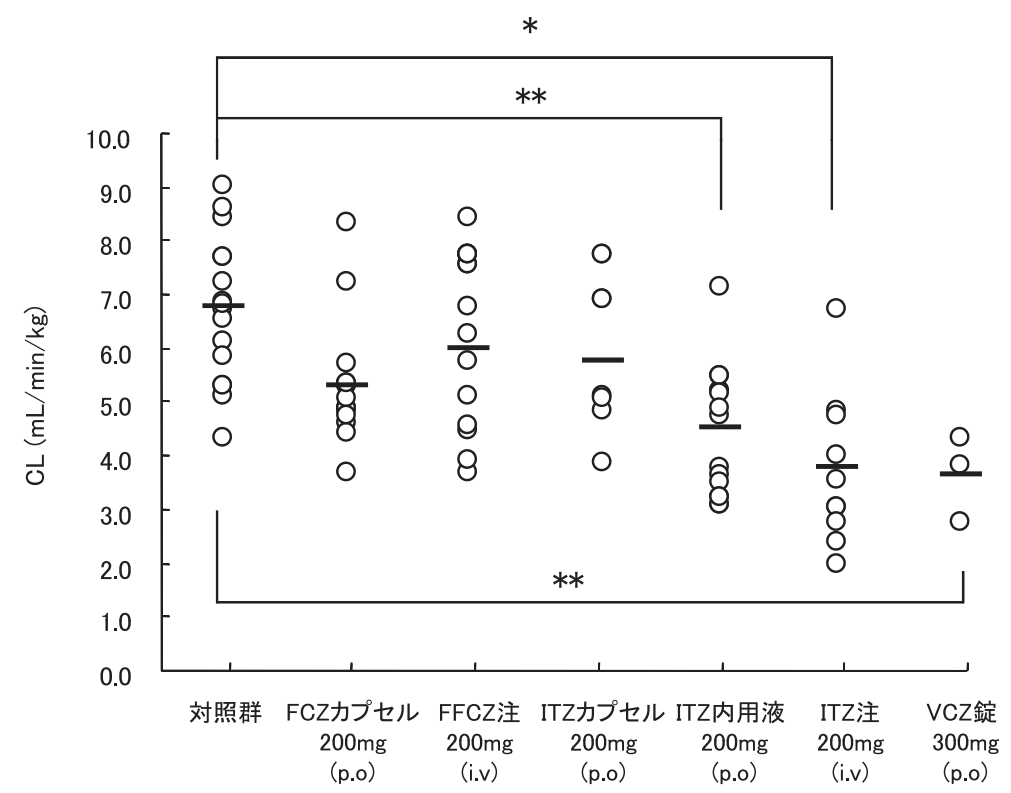

図 $2 \mathrm{CyA}$ 静脈内投与 (i.v.d) 時のクリアランス (CL) に及ぼすアゾー ル系抗真菌剤の影響

各ポイント (○) は同一患者における同一アゾール系抗真菌片使用下での CL の平均值 （測定回数：3〜16 回）, バー（一）は各群の平均值を示す.

${ }^{*} P<0.001,{ }^{* *} P<0.05 \quad$ (Kruskal-Wallis test followed by Dunn's multiple comparison test )

\section{考察}

今回の検討の結果，アゾール系抗真菌剤の種類 や投与経路により CyA との薬物間相互作用に差 異を認めた。ささらに，この相互作用は $\mathrm{CyA}$ の投 与経路，即ち経口と静脈内投与の相違によっても 変動することが明らかとなった。
まず, CyA 経口投与群における，アゾール系抗 真菌剂との薬物間相互作用の強度は ITZ 内用液> $\mathrm{VCZ}$ 錠 $>$ ITZ カプセル $>$ FCZ カプセルとなった. 併用により最も CyA 血中濃度の変動が大きかった ITZ 内用液併用群では, C/D 比は対照群の 3.0 倍 となり，併用に際して CyA 投与量を $70 \%$ 減量す る必要性が示唆された。さらに, VCZ 錠併用群で 
2.1 倍, ITZ カプセル, FCZ プセル併用群におい ても 1.5 から 1.7 倍の上昇を認めたことから，これ らの薬剤を併用する際にも 30 50\%程度 CyA 投 与量を減量する必要性が示された。 なお, 経口投 与群の ITZ 内用液とカプセルの 2 剂形では，内用 液でより大きく CyA 血中濃度が上昇した。本検討 では, ITZの血漿中濃度の測定は実施していない が，ITZカプセルのバイオアベイラビリティー （BA）が $55 \%$ であるのに対して，溶解補助剂とし てヒドロキシプロピル - $\beta$ - シクロデキストリンが 添加された ITZ 内用液の BA は $85 \%$ と向上してお り ${ }^{8,9)}$ 同投与量ではカプセルに比べ内用液におい て ITZの血漿中濃度が上昇したため, ITZ内用液 でより強く相互作用が発現したと推察した。また, CyA を経口投与した際のアゾール系抗真菌剤との 薬物間相互作用についての報告は散見されるが, 各抗真菌剤ごとで患者背景等が異なる．ITZ 内用 液では, CyA 血中濃度は 4.5〜 7.6 倍, ${ }^{10)} \mathrm{VCZ}$ 錠, ITZ カプル, FCZ カプセルでは, それぞれ 3.3 倍, ${ }^{11)}$ 2 3 倍, ${ }^{12)} 1.6$ 倍 ${ }^{13)} \mathrm{CyA}$ 血中濃度が上昇し, これ らの報告をまとめると，打打むね薬物間相互作用 の強度は, ITZ 内用液 $>$ VCZ 錠 $>$ ITZ カプセル > FCZ カプセルとなっており, 今回の我々の検討結 果と同様の傾向を認めた。ささらにアアゾール系抗 真菌剤の in vitro での CYP3A4 阻害活性の強度は $\mathrm{ITZ}>>\mathrm{VCZ}>\mathrm{FCZ}$ との報告がある. ${ }^{14)}$ また今回 検討した ITZ 内用液, VCZ 錠, FCZ カプルの BA はそれぞれ $85 \%,{ }^{8,9)} 100 \%,{ }^{15)} 90 \%{ }^{16)}$ といずれ も高く, 以上のことから推定される相互作用の強 度は ITZ 内用液 $>$ VCZ 錠 $>$ FCZ カプセルとなり， 我々の結果を支持するものであった。

次に, CyA 静脈内投与群における検討の結果, アゾール系抗真菌剤との薬物間相互作用は, ITZ 注，VCZ 錠 $>$ ITZ 内用液 $>$ FCZ カプセル $>$ FFCZ 注, ITZカプセルとなった. 強い薬物間相互作用 が確認されたのは ITZ 注，VCZ 錠併用群で対照群 に比べ CyA の CL が約 50\%, 次いで ITZ 内用液 群で 35\%低下した。従って, VCZ 錠，ITZ 注併用 時には $50 \%$, ITZ 内用液では $35 \%$ の CyA 投与量 を減量する必要があると考えられる。一方，FCZ カプセル，ITZカプセル， FFCZ 注併用群の CL は 約 10〜20\%程度の低下にとどまり，CyA 血中濃度
に及ぼす影響は小さく，併用に際しても 10２0\% 程度の減量でよいと思われる. また, 静脈内投与 では, ITZ製剤として注射剤, 内用液, カプセル の 3 剂形で検討することが可能であったが，相互 作用に伴う CyA 血中濃度の変動はそれぞれの剤 形で異なっており, ITZの BA と同様に ${ }^{8,9)}$ 注射剂 が最も大きく, 次いで内用液, カプセルの順となっ た. 従って, 造血幹細胞移植後, 病態の安定化に 伴い, ITZ 注から ITZ 内用液やカプセル等の経口 剤に変更する際には, CyA 血中濃度の変動に留意 する必要があることが示された。

今回得られた CyA 経口投与群と静脈内投与群 の結果を比較すると, 静脈内投与群では, CyA 薬 物動態に及ぼすアゾール系抗真菌郕の影響が小さ くなる傾向を示した。これは, CyA 静脈内投与で は，主に肝臓での CYP3A4 あるいは P 糖タンパク 質を介する薬物間相互作用が関与しているのに対 し, 経口投与では肝臓に加え小腸における薬物間 相互作用が関与しているため, ${ }^{17,18)}$ 経口投与でより 大きな血中濃度の変動が生じたと考えた. CyA 経 口投与は退院後も継続されることがほとんどであ り，外来では頻回に TDM を行うことができない 場合も多く，実際にアゾール系抗真菌剂が併用さ れた後，血中濃度の実測值であるトラフ值が上昇 した症例も存在するため注意が必要と思われる. 加えて, 静脈内投与については, ほとんどの場合 移植直後に用いられることから, 血中濃度が中毒 域と近接した高い值で維持される。 そのため, ア ゾール系抗真菌剤との相互作用に伴う血中濃度の 変動は経口投与に比べ小さいものの, その血中濃 度の変動にも十分な配慮が必要である。また， CyA を静脈内投与した症例に扮けるアゾール系抗 真菌剤との薬物間相互作用についての報告はほと んどないことから, 本検討の結果に基づき $\mathrm{CyA}$ 投 与量を調節することは, CyA を適正使用するうえ で有用であると考える。しかしながら本検討では, 対象となる抗真菌剤の血中濃度を測定していない ため原因は明らかではないが，いずれの群におい ても C/D 比にばらつきを認めたため, 抗真菌剤の 併用に際して一律に減量することはリスクが高く， 段階的な減量や早期に血中濃度を測定し, 投与量 を調節することが必要であると思われる. 
以上, 今回我々は, アゾール系抗真菌剤との併 用により CyA 血中濃度が大きく上昇する可能性を 示し，これらの薬物間相互作用が CyA 投与経路 や各アゾール系抗真菌剤の種類や剤形により異な ることを明らかにした，造血幹細胞移植後の CyA とアゾール系抗真菌剤の併用機会は多く, TDM の際，本検討結果に基づき CyA 投与量の調節を 提案していくことができればより安全かつ有効な 治療を患者に提供することができると思われる.

\section{利益相反}

本稿に関する特記するべき利益相反はない。

\section{謝 辞}

本研究にご協力いただきました京都大学医学部 附属病院薬剂部の増田智先先生並びに桂 敏也先 生に感謝いたします。

\section{引用文献}

1) Campana C, Regazzi MB, Buggia I, Molinaro M, Clinically significant drug interactions with cyclosporin, Clin Pharmacokinet, 1996, 30, 141-179.

2）梶田貴司, 上田睦明, 西川 豊, 橋本亜衣子, 東 康彦, 今村政信, 毎田千恵子, 中塚英太郎, 藤井 洋一, 宮本悦子, シクロスポリン Aとメシル酸イ マチニブの薬物間相互作用の検討を行った骨髄 移植患者の 2 症例, TDM研究, 2007, 24, 137-143.

3) Saad AH, DePestel DD, Carver PL, Factors influencing the magnitude and clinical significance of drug interactions between azole antifungals and select immunosuppressants, Pharmacotherapy, 2006, 26, 1730-1744.

4) Gillum JG, Israel DS, Polk RE, Pharmacokinetic drug interactions with antimicrobial agents, Clin Pharmacokinet, 1993, 25, 450-482.

5) Wang EJ, Lew K, Casciano CN, Clement RP, Johnson WW, Interaction of common azole antifungals with P glycoprotein, Antimicrob Agents Chemother, 2002, 46, 160-165.

6) Tapaninen T, Backman JT, Kurkinen KJ, Neuvonen PJ, Niemi M, Itraconazole, a P-glycoprotein and CYP3A4 inhibitor, markedly raises the plasma con- centrations and enhances the rennin inhibiting effect of aliskiren, J Clin Pharmacol, 2011, 51, 359-367.

7）西川 豊, 梶田貴司, 住川麻依, 黒松 誠, 吉田 裕美, 上田睦明, 中塚英太郎, 中村文彦, 小柳 悟, 大戸茂弘, 同種造血幹細胞移植患者におけるシ クロスポリンA血中濃度と副作用発現に関する 検討, 日本病院薬剤師会雑誌, 2010, 46, 351-354.

8) Prentice AG, Donnelly P, Oral antifungals as prophylaxis in haematological malignancy, Blood Reviews, 2001, 15, 1-8.

9）イトリゾール®カプセル50, インタビューフォー ム, ヤンセンファーマ株式会社, 2010年12月改訂 (第11版).

10）山口佳津騎, 河添 仁, 井上達也, 田中裕章, 二宮 昌樹, 福岡憲泰, 芳地 一, イトラコナゾール内 用液がシクロスポリンの薬物動態に及ぼす影 響, 日本病院薬剤師会雑誌, 2009, 45, 1494-1496.

11）高嶋美季, 谷口理沙, 矢野育子, 甲野貴久, 橋田 亨, 増田智先, 石川隆之, 内山 卓, 乾 賢一, 造 血幹細胞移植患者におけるカルシニューリン阻 害剂とアゾール系抗真菌剤の薬物動態学的相互 作用の評価, 医療薬学, 2009, 35, 233-239.

12）平井正巳, 龍尾恵美, 市川正孝, 移植患者のシク ロスポリン血中濃度に及ぼすアゾール系抗真菌 剂の投与量依存性の影響, TDM研究, 1998, 15, 218-224.

13）浜之上恵美, 小杉隆祥, 木村伊都紀, 松尾和廣, 黒川 實, 相川 厚, 水入苑生, 小原武博, 長谷川 昭, C2モニタリングによりシクロスポリンAと フルコナゾール及びクラリスロマイシンとの薬 物相互作用の検討を行った生体腎移植患者の一 症例, 医療薬学, 2003, 29, 744-749.

14）丹羽俊朗, 白神歳文, 高木 明, 抗真菌剤の薬物 相互作用一薬物代謝酵素に及ぼす影響 一, 薬学 雑誌, 2005, 125, 795-805.

15）ブイフェンド®錠, インタビューフォーム, ファ イザー株式会社, 2011年10月改訂（第 9 版）.

16） ジフルカン®カプセル, インタビューフォーム, ファイザー株式会社, 2012年 2 月改訂 (第14版).

17) Wu CY, Benet LZ, Hebert MF, Gupta SK, Rowland M, Gomez DY, Wacher VJ, Differentiation of absorption and first-pass gut and hepatic metabolism in humans studies with cyclosporine, Clin Pharmacol Ther, 1995, 58, 492-497.

18) Kato M, Intestinal first-pass metabolism of CYP3A4 substrates, Drug Metab Pharmacokinet, 2008, 23, 87-94. 